\title{
Exploration of Potential Public Housing Strategies for Low-income Households in Yangon, Myanmar
}

\author{
Yin Mon NAING, Kyoto University, Japan \\ Sung Lun TSAI, Kyoto University, Japan \\ Hirohide KOBAYASHI, Kyoto University, Japan
}

\begin{abstract}
This study aims to explore the possible applications of public housing strategies in Singapore, Taiwan and Thailand to Yangon through examining their compatibilities in governance, sociopolitics and economic contexts. Based on the current situations of Yangon, the policy transferability from Singapore can be difficult while there is a potential to adopt the policies implemented in Taiwan and Thailand. Singapore's large-scale direct provision requires a strong commitment from the government; however, this aspect along with urban-rural migrations is a major constraint in Yangon. Considering the capacities of Department of Urban and Housing Development (DUHD), it is suggested to adopt various housing alternatives with more participatory approach. There is a potential to integrate Taiwan's ways of private-public partnership rental housing program into Yangon's public housing scheme but this would require updating of the current regulations to remain affordable for low-income families. Though it might be difficult for DUHD to fully operate as Community Organizations Development Institute (CODI) due to the centralized governance structure, it provides an alternative way for bottom-up approach in housing delivery for urban poor. The findings of this study can be applicable to both Yangon and other similar countries to solve the housing shortage problems while creating conditions of equity and affordability for low-income households.
\end{abstract}

\section{Keywords}

Public housing, Low-income households, Policy transferability, Asian countries, Yangon

\section{Introduction}

Though housing is the basic right for everyone, many households were struggling to find the affordable accommodations especially in developing countries (Stephens, 2010, Chen et al., 2011). In the recent years, Myanmar had experienced the rapid economic growth in the cities, where the annual GDP growth in Yangon grew at an average 9.2\% between 2012 to 2017 (PwC, 2018). Such rapid growth brought large amount of rural migration to the cities while $20 \%$ of the current rural population were expected to move to Yangon and Mandalay by 2050, straining the capacities of cities' resources and services. According to Asian Development Bank (ADB), the aggregate housing shortage for Yangon could be reached to nearly 600,000 units by 2030 where nearly half of them needed to be non-market housings for middle- and lowincome households (ADB, 2019).

Therefore, to ease the severe housing problems of low-income households, public housing programs were initiated and delivered in two approaches in Yangon: (i) direct-provided affordable and low-cost housing program named "One Million Housing Program" for middle-income group (MIG) and low-income 
group (LIG) and (ii) NGO-supported community-led housing program for informal dwellers. Despite those initiatives, the housing shortage of low-income households still existed due to the delay and financial limitation in "One Million Housing Program" while the community-led housings were implemented only in small scale. There was in need of a review and a paradigm shift in the current public housing policies and approaches for Yangon to address the growing urgency of providing adequate and affordable housing to millions of households (Carrasco and Shah, 2018).

In policy-remaking process, a common step includes investigating how other governments had addressed the similar situation and whether the successful experience could be transferrable or not (Wei et al., 2017; Chiu, 2013). Such analysis of policy transferability could reduce the uncertainties caused by the introduction of new policies (Wei et al., 2017). However, this kind of study has been under-discussed particularly in the comparative housing literature which usually focused in the European and North American context (Wei et al., 2017). Thus, this study aims to investigate the potential public housing policies and approaches for low-income households that could be applicable in Yangon by drawing on the experiences from the neighbouring countries in Asia such as Singapore, Taiwan and Thailand.

\section{Methods}

This study aims to explore the possible applications of public housing policies and approaches for Yangon through examining those in other Asian countries. Singapore, Taiwan and Thailand were selected for the referring case countries according to their different levels of maturity in public housing provision along with the states of countries and economies.

The study is built on the systematic reviews of the secondary data on public housing policies and practices in selected countries, with a follow-up semi-structured interview with key informants. The literatures included the articles, research reports, dissertations, and governmental records and reports on public housing policies. The interviews were conducted with the officials from Department of Housing and Urban Development (DUHD) to learn about the challenges in the public housing system in Yangon. The study begun with the overview of the public housing policies and programs in Myanmar, along with the issues in the current public housing system. Then, public housing policies in three Asian countries were reviewed focusing on the governance structures, policies and practices related to the public housing development and the factors that led to the success and failure of the development. The feasibility of transferring public housing policies and practices from the case study countries to Yangon city were examined and discussed at two levels such as macro (socio-political and urbanization context) and meso (legal, institutional and financial context) levels.

\section{Public housing in Myanmar}

This section discusses the transition of public housing provision in Myanmar under different political governance systems between 1950 and 2020 including the challenges in current public housing system identified through literature reviews and key informants' interviews.

\subsection{Transition of public housing development in Myanmar}

In Myanmar, public housings were mainly developed in Yangon and its strategies had evolved through three discernible periods according to the transition of urban growth and the political conditions of the country. As shown in Figure 1, the first period of public housing was started in Yangon in 1950 due to the severe housing shortage from a rapid population growth in the city. During the period between 1950 to 1980 , public housings were provided as social need. Then the second phase kicked in due to another population boom and political changes in the city (Nwal and Panuwatwanich, 2018; Naing and Nitivattananon, 2020; Heeckt et al., 2017). The third strand started in 2010 after the country was 
transitioned to democracy and public housings were delivered again to address the growing informal settlements in the city which made up approximately 500,000 people in 2018 DUHD survey (Naing and Nitivattananon, 2020a).

As the first step of development, the National Housing Board (NHB) was established in 1951 as the main implementing agency for housing development and several policies and regulations regarding property rights and rent control were enacted (ADB, 2019). During these periods, the public rental housings were delivered under the concept of "No profit - No lose", targeting only middle-income households as the beneficiaries of the scheme. Due to the prolonged budget constraint, the funding to the rental housings for the public was halted and continued only as the government staff housings until late 1980s (Kraas, Faese and Kyi, 2006).

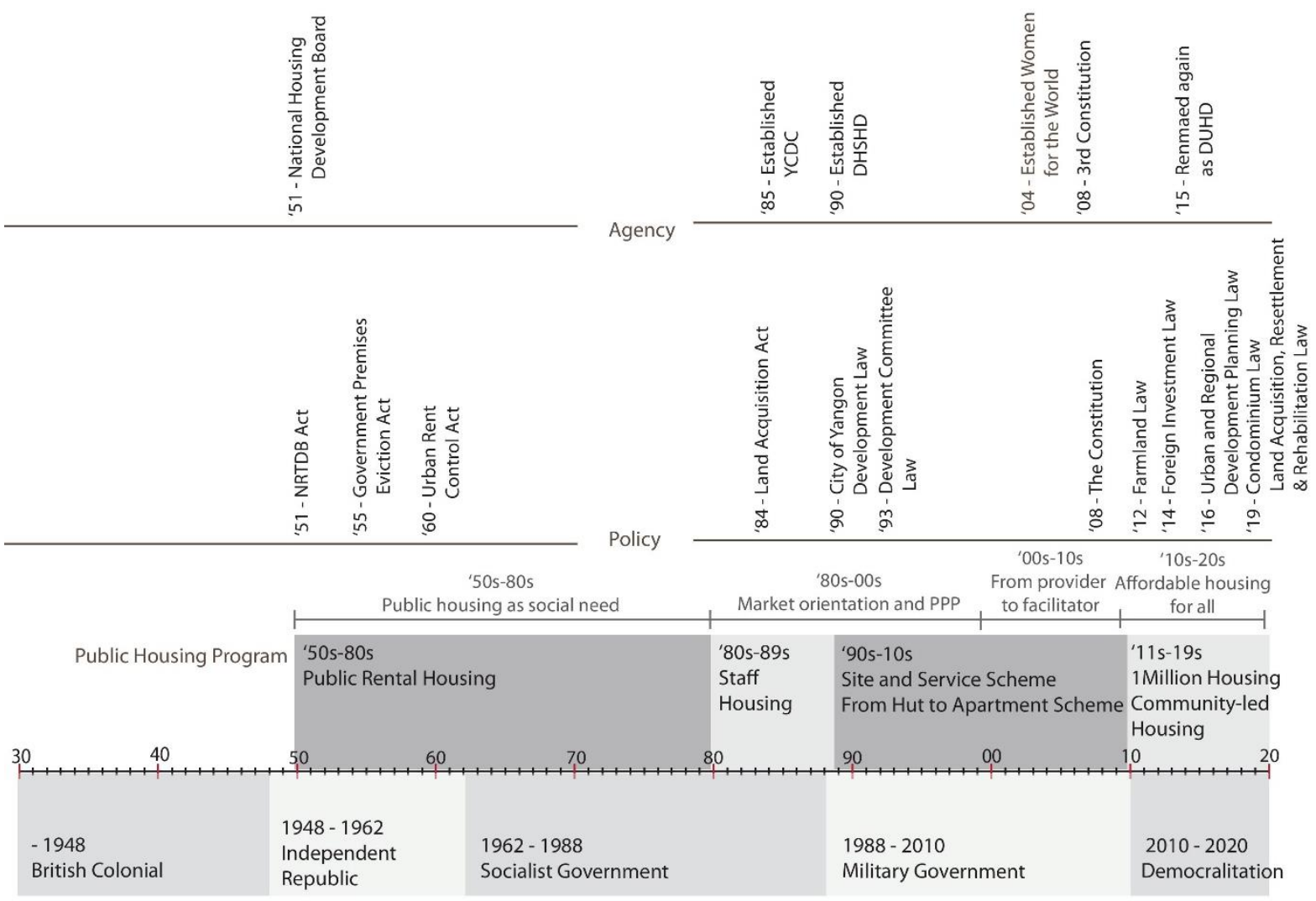

Figure 1 Evolution of public housing policies and programs in Yangon, Myanmar. Source: Modified from Lall, Mitra and Sakuma, 2018.

Since then, Department of Human Settlement and Housing Development (DHSHD) which was reorganized from NHB under the military government focused on area development and changed its role from housing provider to facilitator by letting the private sector to take over the market (Nwal and Panuwatwanich, 2018). Being largely privatized, the housing market grew rapidly but became unstable and monopolized by the estate developers. As a result, a large numbers of informal settlements were appeared in the city center but were forced to relocate to new satellite townships in late 1980s under the program called "site and service scheme" (Naing and Nitivattananon, 2020a; Kouri, et al., 2020). DHSHD also conducted "from hut to apartment scheme" together with private sector to upgrade the informal settlements in inner urban ring (Naing and Nitivattananon, 2020a). However, the program was ineffective in upgrading the informal settlements as many of informal dwellers sold their permits or properties to the other well-off families or the developers and moved to the cheaper houses in outskirts or other informal settlement areas. 
The third policy strand under the democratic government focused on the revision of outdated regulations and the placement of new policies to stimulate private sector investment in high-end and estate development (Nwal and Panuwatwanich, 2018). As of 2020, National Housing Development Policy was under the draft to provide a regulatory framework and direction for affordable and low-cost housing development while the local government restarted the provision of low-cost housing units to the public through Yangon Region Government (YRG) and Department of Urban Housing and Development (DUHD) which was restructured from DHSHD in 2015 (Lall, Mitra and Sakuma, 2018).

\subsection{Current situations of public housing and the challenges}

\section{- Governance structure}

The governance system in Myanmar has been centralized for a long time and this particularly applies to the governance structure in Yangon where top-down system and a complex governance system was in place. The administration structure generally consists of three levels as union, regional and state, and city level. The regional and state parliament could independently enact laws and regulations for their own department at city level. Currently, there is Ministry of Construction at union level which has DUHD at regional level, the main agency in public housing development. Another regional key stakeholder in housing provision is YRG which is responsible for rule of law and investment support for developments in Yangon. At the local level, there is Yangon City Development Committee (YCDC) to issue the construction permits and the delivery of basic urban services (ADB, 2019). Since the development of public housings was not paid attention by the central authorities for a long time, many gaps were left in the system especially in terms of policy.

- Current situation of public housing provision in Yangon

Due to the political instabilities over decades (1962-2011), public housing sector in Myanmar has not matured yet (Naing and Nitivattananon, 2020b). The housing market in Yangon has largely privatized and serves mainly for high-income households where most of the low-income households are forced to live in informal settlements. To address the affordable housing shortages for LIG, public housings have been delivered in two approaches as follows -

(i) Direct-provision system: The "One Million Housing Program" is a 20-years (2011-2030) program with four phases where $20 \%$ is responsible by DUHD and $80 \%$ by the private sector (ADB, 2019). Housings were built on the DUHD owned land and its own revolving fund (72 million USD) as the financial capital. Housing eligibility is determined by the income threshold between $300-500$ thousand MMK (180-300 USD) targeting to lower-middle income group. The buyers could apply the mortgage loan from the Construction, Housing and Infrastructure (CHID) Bank up to 70\% of the property's value if they could deposit that of $30 \%$ to the bank (Nwal and Panuwatwanich, 2018).

In this context, lack of proper policy planning along with the outdated acts from colonial period made the complexity between the government departments and the overlap of functions thereby creating confusion over responsibilities (Kouri, et al., 2020). This affected to the delivery of the housing in timely manner, including the land acquisition process. On the other hand, DUHD has been facing financial difficulties and it is more likely to be challenging for the last two phases as they are going to have more units to complete. As the financial source is only from the revolving fund of the DUHD, they need to maintain the sale of housing units. To avoid deficits and sell-out their completed housing units before next phase, DUHD had to establish an income threshold and requirement to make $30 \%$ down-payment which made unaffordable to LIG and resulting the ownership mostly by MIG (Nwal and Panuwatwanich, 2018; Naing, 2018). Even though it was expected the private sector would provide $80 \%$ of the quota, the unchanged high construction tax (30\% of the total building construction cost) placed stress on private developers. It was also inevitable that the low-quality building materials were 
being used to reduce the construction cost and unit floor area. Though DUHD had hired a third party to manage quality control, it was ineffective due to the lack of building standards for public housing, while DUHD also did not see this issue as important (Nwal and Panuwatwanich, 2018).

(ii) Community-led housing: It is the community-led project initiated by the local NGO called Women for the World (WfW) where the informal dwellers were positioned as the implementer and owner of the project (Naing and Nitivattananon, 2020a). Though the program had paved an alternative way to provide housing particularly for the poor in Yangon, the implementation had difficulties in scaling-up due to the limited financial and technical capabilities (Kouri et al., 2020). In 2019, WfW was able to collaborate with the government officials such as DUHD and YRG to start the pilot program which would provide 50,000 housing units for the informal households in six different townships in Yangon. The collaboration brought the land and infrastructure subsidies from YRG which could ease the financial burden of the local communities.

\section{Public housing within Asia: Singapore, Taiwan and Thailand}

This section discusses the policies and practices regarding public housing development in Singapore, Taiwan and Thailand. It focuses on the governance structure and the policies and practices that enable or fail the development in their regions. Table 1 provides the overview of each country with respect to the major attributes of their housing systems.

\subsection{Singapore}

In Singapore, public housing was regarded as a political good and a driving force of the country's economy. The government set housing as a priority issue and planned to provide it on a large scale, granting a high level of power and public subsidies to the implementing agency (Phang, 2018). As a result, $82 \%$ of the population lived in those public housings and $90 \%$ of which owned their houses (JICA, 2013).

\section{- Governance structure}

The Housing Development Board (HDB) which was established in 1960, is the only statutory agency to construct and manage Singapore's public housings. It manages the whole cycle of public housing program, enabling to become an autonomous agency (Wei et al., 2017; Haque, 2004; Joo and Wong, 2008). The board of HDB is comprised not only with the government officials but also government appointed professional leaders, interest group leader and academia. Though the decision-making process of HDB was not clear, earlier process could be the centralized approach with no resident representative, but it was changed into partial decentralization in 1989 along with the introduction of town councils to address the diverse needs and preferences of residents (Wei et al., 2017). Town council inhere acts as intermediary between local people and decision-makers at nation level while it also has the right to make decisions for the policies implementation (Joo and Wong, 2008).

- Policies and practices

If political stabilization and strong commitment from government were the contributing factors to success of public housing in Singapore, its policies and practices had enabled the implementation. Singapore's land policy has facilitated the large-scale housing provision by allowing to acquire the land at low cost. Due to the 1966 Land Acquisition Act, HDB could obtain the private land at lower market cost for the housing development leading to the decrease in implementation cost thereby able to make affordable for the buyers (Phang, 2018; Wei et al., 2017). This act let the government take control over the land market in the city state almost as monopoly which guaranteed the large supply of public housing (Lum, 2002). 
According to the Housing and Development Act, HDB could get loans and grants to implement the housing program which allowed HDB as the dual player of developer and banker (Joo and Wong, 2008). The deficits were covered by the government grants and in 2014 it had received a cumulative of nearly $\$ 25$ billion. To mobilize the sale, HDB initiated an innovative financial scheme for the buyers namely the Central Provident Fund (CPF) saving. It is the compulsory saving scheme established in 1968 for every working Singaporean and permanent residents which both employees and employers have to contribute their savings of $20 \%$ and $17 \%$ respectively. Since then, CPF has been the main source of funding for the buyers that leads to the rapid increase of home ownership (Phang, 2018: Wei et al., 2017).

\subsection{Taiwan}

The housing market in Taiwan had long been struggling with the high prices especially in urban area like Taipei where the house price-to-income ratio was risen in double in last decade. Thus, a lack of affordable housing for LIG had remained for many years but the democratization process and the urge from prosocial housing NGOs resulted the central government to ratify the "Residential Act" in 2011 (Ministry of Interior, 2020). The act could be deemed as a significant paradigm shift of the social housing policy in Taiwan.

\section{- Governance structure}

Ministry of Interior (Mol) and the Department of Urban Development (DUD) are the key public stakeholders at central and local level respectively. Mol is responsible for formulating policies and regulatory acts including financial plans and subsidies for DUD while DUD is to set the regional social housing plan and the implementation of social housing stocks. Moreover, Mol established the public institution namely National Housing and Urban Regeneration Center (NHURC) to support DUD in assets management and business development regarding social housing affairs. Though current policies and acts had developed internally within the government agencies, the public concerns were considered through the lobby of the pro-social housing NGOs.

- Policies and practices

The current "Residential Act" that was developed under Executive Yuan in 2011 is the key policy and its strategies mainly focus on the direct provision of the rental housings and the public-private program called Owner-Tenant Platform (OTP). Newly-built social housings were developed as part of urban renewal or new town development aiming not only to address the affordable housing shortage for LIG but also to develop more liveable neighbourhoods. All the social housings under this strategy included both the accommodations and the common facilities, targeting to the tenants whose income are below the 50 percentile and no homeownership. Among them, 30\% of the stocks would be allocated to the socio-economically marginalized groups (Laws and Regulations Database of The Republic of China, 2017). However, due the limited budget of DUD in small cities, housing stocks were mostly developed in the metropolitan area. Therefore, an intermediary financial platform called Financing Platform Service was established to facilitate the low-interest and long-term funds to the local DUD in small cities (Ministry of Interior, 2019).

Meanwhile, the OTP is another strategy in providing affordable rental housing stocks to reach the targets through collaborating with existing private homeowners. The platform aims to match the house owners who are willing to rent their houses in low rate $(80 \%$ of market price) to the tenants through the governmental-initiated property companies (Ministry of Interior, 2021). This platform has also enabled the untransparent housing rental market in the country with substandard housing quality. Taiwan also has various forms of rent allowance and subsidy for different types of households who would like to lease the house in the private market (Chen, 2011). 


\subsection{Thailand}

The state of public housing in Thailand is still emerging where the market is largely led by the private sector, with the limited role from the government. Though the economy in the country had been growing, the home ownership in the big cities like Bangkok metropolitan region (BMR) decreased to 50\% in 2010 from 61\% in 1990 due to a large number of migrants living in rental flats (JICA, 2013).

- Governance structure

In Thailand, the National Housing Authority (NHA), the Community Organizations Development Institute (CODI) and the Government Housing Bank (GHB) are the major government agencies in public housing development. GHB was established in 1953 under Ministry of Finance to provide housing finance to developers and first-time buyers. NHA is a state enterprise that operates under the National Housing Authority Act and is responsible for developing, supporting and facilitating housing MIG and LIG (RICS, 2019; JICA, 2013). As it operates in a semi-official capacity, it has more flexibility than other government departments; however, it is expected to be a self-supporting agency with the right to borrow necessary funds from the government or public by issuing bonds (RICS, 2019). Lastly, CODI is the restructured public autonomous organization founded in 2000 under the same ministry with NHA. CODI operates more like a non-profit organization at city level and applies community-driven approach to bridge the gaps between the state decision-makers and the poor communities (RICS, 2019; JICA, 2013).

- Policies and practices

Thailand currently does not have a comprehensive national policy and works under the direction of National Economic and Social Development Plan which is updated every five years. The latest housing development was implemented in 2003 under the Prime Minister Thaksin namely "One Million Housing program" as part of political strategy. The program included the NHA to build 600,000 units (Baan Eua Arthorn or BEA Program) and CODI to upgrade another 300,000 units in the existing communities (Baan Mankong or BMK Program). Another 100,000 units were assigned to GHB to finance (JICA, 2013).

Without a comprehensive housing policy or unified governmental approach towards housing, problems had arisen in BEA program, pertaining to the role of NHA (JICA, 2013). During the implementation of BEA program, the NHA faced the housing surplus and criticized for immense funding use and for corruption (Leeruttanawisut and Fukushima, 2017). The strategy "one price fits all policy" placed all the housing supplies and sale price the same for every province in Thailand while the demand and affordability rate between the BMR and other provinces were varied. This led to the housing surplus and later eliminated such policy and made it more flexible housing prices according to the provinces (Leeruttanawisut and Fukushima, 2017). However, too much relaxation of income ceiling resulted in many MIG $(62.3 \%$ of ownership) as the beneficiaries instead of LIG (RICS, 2019).

On the other hand, BMK project led by CODI paved an innovative way to solve settlement and tenure security problems of slum inhabitants in countrywide. In the initial stage, the low-income communities worked together with their local government and other professionals to develop plan and upgrading process in city-wide scale. Once the plans were finalized, CODI provided infrastructure subsidies from the central government and/or CODI's housing loans to the communities through legally established cooperatives or saving groups (JICA, 2013). Based on the BMK program, CODI also initiated several financial programs to support the NGOs and the communities. 
Table 1 Overview of public housing strategies in Singapore, Taiwan and Thailand.

\begin{tabular}{|c|c|c|c|c|c|c|}
\hline Country & Governance & $\begin{array}{c}\text { National housing } \\
\text { policy }\end{array}$ & Main strategies & Finance & Land & Beneficiaries \\
\hline Singapore & $\begin{array}{l}\text {-HDB as main } \\
\text { implementing agency } \\
\text {-HDB as autonomous } \\
\text { agency with } \\
\text { autonomy in } \\
\text { financial, personnel } \\
\text { and other managerial } \\
\text { matters }\end{array}$ & $\begin{array}{l}\text { - Large scale public } \\
\text { housing and } \\
\text { subsidised home } \\
\text { ownership program } \\
\text { to make affordable }\end{array}$ & $\begin{array}{l}\text { Direct provision and } \\
\text { promote home } \\
\text { ownership } \\
\text { - Indirectly control } \\
\text { prices in private } \\
\text { housing market } \\
\text { - Income ceiling to } \\
\text { measure } \\
\text { affordability }\end{array}$ & $\begin{array}{l}\text { - Central provident } \\
\text { fund (CPF) } \\
\text { - Central } \\
\text { government } \\
\text { subsidies and } \\
\text { grants }\end{array}$ & $\begin{array}{l}\text { - Owned by the } \\
\text { government } \\
\text { - the Land } \\
\text { Acquisition } \\
\text { Act allows } \\
\text { HDB to } \\
\text { acquire the } \\
\text { land at } \\
\text { below- } \\
\text { market price }\end{array}$ & $\begin{array}{l}\text { - Middle and } \\
\text { low income } \\
\text { groups }\end{array}$ \\
\hline Taiwan & $\begin{array}{l}\text { - MOI at national level } \\
\text { and DUD at local level } \\
\text {-Although local } \\
\text { government is } \\
\text { responsible to plan } \\
\text { and construct the } \\
\text { social housing stock } \\
\text { by themselves, the } \\
\text { NHURC can also } \\
\text { directly construct the } \\
\text { public housing align } \\
\text { with the national } \\
\text { policy }\end{array}$ & $\begin{array}{l}\text { - National housing } \\
\text { policy under } \\
\text { Executive Yuan } \\
\text { - Focus on the } \\
\text { middle- and low- } \\
\text { income family to } \\
\text { solve the problem } \\
\text { of unaffordable } \\
\text { rents or prices of } \\
\text { housing }\end{array}$ & $\begin{array}{l}\text { - Target to the } \\
\text { middle- and low- } \\
\text { income and } \\
\text { socioeconomic } \\
\text { marginalized groups } \\
\text { - Aim to provide } \\
\text { affordable rental } \\
\text { housing through } \\
\text { newly-built stocks } \\
\text { and subleasing from } \\
\text { private owners }\end{array}$ & $\begin{array}{l}\text { - Low-interest, } \\
\text { long-term loans } \\
\text { for the local } \\
\text { government } \\
\text { - Subsidized rents } \\
\text { for } \\
\text { disadvantaged } \\
\text { tenants } \\
\text { - Subsidies and } \\
\text { taxation for the } \\
\text { participating for } \\
\text { landlords }\end{array}$ & $\begin{array}{l}\text { - Owned by the } \\
\text { government } \\
\text { - Can be } \\
\text { acquired non } \\
\text { state-owned } \\
\text { land for } \\
\text { public use } \\
\text { without } \\
\text { remuneration } \\
\text { by local } \\
\text { government }\end{array}$ & $\begin{array}{l}\text { - Middle and low } \\
\text { income groups } \\
\text { including socio- } \\
\text { economic } \\
\text { marginalized } \\
\text { groups }\end{array}$ \\
\hline Thailand & $\begin{array}{l}\text {-NHB as state } \\
\text { enterprise developer, } \\
\text { CODI as NGO like } \\
\text { public organization } \\
\text { GHB as banker } \\
\text {-Decentralized to local } \\
\text { government } \\
\text { - Largely privatized } \\
\text { housing market and } \\
\text { limited role of } \\
\text { government }\end{array}$ & $\begin{array}{l}\text { - No comprehensive } \\
\text { housing policy } \\
\text { - Focus on provision } \\
\text { of housing loans for } \\
\text { home purchase }\end{array}$ & $\begin{array}{l}\text { Promote home } \\
\text { ownership and the } \\
\text { establishment of } \\
\text { community } \\
\text { networks to building } \\
\text { low-cost housing }\end{array}$ & $\begin{array}{l}\text { - Limited funding } \\
\text { from the central } \\
\text { government } \\
\text { - Promote public- } \\
\text { private/ } \\
\text { community } \\
\text { partnership }\end{array}$ & $\begin{array}{l}\text { - Individual } \\
\text { land } \\
\text { ownership } \\
\text { thus expense } \\
\text { for land took } \\
\text { up nearly } 60 \% \\
\text { of total cost } \\
\text { - Built on NHB } \\
\text { owned land }\end{array}$ & $\begin{array}{l}\text { - Initially low- } \\
\text { but middle- } \\
\text { income groups } \\
\text { were mostly } \\
\text { benefited } \\
\text { - Poor/Informal } \\
\text { dwellers }\end{array}$ \\
\hline
\end{tabular}

Source: RCIS, 2019; Ministry of Interior, 2019; Ministry of Interior, 2020.

\section{Discussion}

The potential of policy transferability from the selected three countries to Yangon were discussed as follows according to the compatibilities of governance structure, financial capacity and socio-political contexts between the originating (Singapore, Taiwan, and Thailand) to the borrowing (Yangon) housing system.

\section{- From Singapore to Yangon}

Considering the current situation of Yangon, it would be difficult to fully replicate Singapore's public housing policy. The success of Singapore's large scale direct provision approach was driven by a strong commitment from the government along with the guidance of a mature public operation system (Chiu, 2013; Wei et al., 2017). HDB possesses many years of experiences in continuous provision of public housing while its autonomous status has made a more flexibility and authority necessary for the large scale implementation. However, in Myanmar, public housing has never received much attention from the central government resulting in a limited financial support and a leapfrog development as part of political movement of the local government. Hence, it is not surprising that DUHD encountered the challenges in implementing current housing program without the enabling conditions like Singapore.

Currently, DUHD has been building on their own land which may later need to acquire from outside (Nwal and Panuwatwanich, 2018). Yet Myanmar was able to revise Land Acquisition, Resettlement and Rehabilitation Law in $\mathbf{2 0 1 9}$, it is difficult to apply in actual situation due to the complex land tenure 
system that was governed by over 50 different laws that overlaid with customary land tenure systems and practices. Although it could be improved further by revising other related regulations and acts, it would take much longer time. Moreover, Yangon is a rapidly developing city that has a fierce competition for land resources resulting in high price of land sales which generate higher sales tax and fiscal revenue that is necessary for the state government. The land pressure adds more cost and heavier financial burden on the local government and cannot be sustained this type of provision without political pressure from the central government, together with clear directions and authority for local government (Wei et al., 2017).

In addition, unlike Singapore, DUHD also needs to take into account a large numbers of poor migrants who are not eligible in the current housing program. Promoting home ownership resulted in limitations in eligibility in terms of income ceiling and the capability to make down-payment. Even in city like Yangon, most of the applicants were found struggling to do monthly saving to make down-payment to get loan application because of the limited household income (Nwal and Panuwatwanich, 2018). Taking the cue of the said challenge, it might not be easy to transfer Singapore's CPF mechanism due to the different economies level between two countries and such mechanism is more likely to bring the benefits to those at average or more than average income group instead of low-income and urban poor.

- From Taiwan to Yangon

Given the similar governance system and huge scale of migrants resulting from rapid urbanization, Taiwan's public housing strategies adopted in the big cities (e.g., Taipei) could be a potential direction for Yangon's public housing development particularly for low-income families. Taipei has long been struggled with the lack of affordable housings for low-income households, but the current strategy focuses on the interest of socio-economic marginalized group, along with the flexibility in policies that enable land acquisition, finance and private provision of public housing with state facilitation.

Since the ownership approach brought burden to both the supplier (DUHD) and the buyers (low-income households) in Yangon, DUHD could promote the rental housing program for low-income families and poor in the city. Taking the advantage of already established rental housing market in Yangon (Naing, 2021), DUDH could bring the low-cost housing owners to the formal rental market as Taiwan government has done by providing the subsidies to the house owners and appointing the estate companies for the management of the renting affairs. However, to adopt this model, the implementing agency of Yangon would need a starting fund to provide the subsidy which the local government cannot afford or are unwilling to pay for. Another risk is the exploitation of private sector that needs to take under control by laws which in turn requires for the revision of Urban Rent Control Act in 1960 to meet the needs.

\section{- From Thailand to Yangon}

Among three countries, Thailand and Myanmar shared the similar patterns and conditions in public housing provision to the low-income households. Without a comprehensive national housing policy, the practices of two countries had been leapfrogged and the reactive actions only as the political move. In this context, DUHD could take the lessons from NHA in implementing and managing the direct provision housing program that promoted home ownership for low-income households. According to Leeruttanawisut and Fukushima (2017), NHA's BEA program was likely to fail to provide affordable housings to the low-income households due to its populist housing policy and limitations in the implementing agency. It is therefore learnt that direct housing provision approach is more suitable for the middle- and lower-middle-income families to prevent the deficits to the agency.

Though it is not possible to replicate the whole community-driven BMK program, it could be partially applied as an additional option to reach the targets of "One Million Housing Program" of Yangon. Due to the heavily centralized governance system and the limited human resources capacity, DUHD might face challenge in reorganizing and acting as CODI's autonomous organization structure. In this context, it 
provides DUHD the ways to strengthen its network with NGOs and communities with the earnest efforts from the local government.

Another threat to the community-led housing program in Yangon is the unstable land subsidies from YRG since it depends on the elected government as YRG is organized with the members of elected government whose commitments would be different from each other. This situation could be improved by DUHD collaborating as loan provider to the communities similar to CODI did since there are currently only two banks that are providing housing loans to the poor communities in Yangon. CODI has used both the central government's grants and its revolving funds to provide loans. In this regards, DUHD could use part of their revolving funds as it is more flexible from being their own budget while the loan itself is constructed to make sure the repayment through being collective and keeping both NGO and all community members as personal guarantee on the loan. The same loan terms could be applied as the income level between Bangkok and Yangon is within the similar range. The mechanism would not only add more alternatives and capital for the communities but also generate more funding to DUHD through interest rate.

\section{Conclusions}

The study focuses on possible policy actions to provide affordable housings for low-income households in Yangon by examining the characteristics and transferability of public housing strategies implemented in three countries in Asia - Singapore, Taiwan and Thailand. It is learnt that the direct provision approach requires strong commitment from the government, along with adequate policies and fundings as it did in Singapore. Absence of these conditions could lead to the corruptions and the failure to reach the targeted supplies and beneficiary groups. Therefore, Taiwan and Thailand were later found to adopt a mix of various approaches such as direct provision method with public private partnership rental approach (in Taiwan) and with community-driven approach (in Thailand) .

Considering these lessons-learnt, the public housing development in Yangon should consider not only the ownership, direct provision approach but also a more consultive and participatory approach. Based on the context of Yangon, the policy transferability to the city from Singapore can be difficult while it is partially possible from the case of Taiwan and Thailand. The differences in governance, the state of economies and urban setting along with the commitment from the central government make the transferability of Singapore's public housing model to Yangon difficult. On the other hand, Yangon could consider for Taiwan's public private partnership approach in affordable rental housing provision since Yangon already has the private rental market. But this would require alternative source of funding to provide subsidy for the private home-owners as well as updating of the Urban Rent Control Act to protect the affordability for low-income families. Thailand's community-driven housing approach could be another alternative approach however the top-down administration that had been embedded in the Myanmar governance system for many years restricted the local government to adopt the whole model. Thus, it can be partially applied in terms of infrastructure subsidies and loans provision to the NGO and communities by maintaining the networks.

This study details different housing strategies in Asian countries and suggests the future direction for affordable public housing development in Yangon, Myanmar. It moves the policy in Yangon toward a hybrid and more participatory direction by strengthening the housing rental market from private sector while also introducing the power of NGO and community social capital in managing public housing for low-income households and the poor. The study is also applicable not only to the cities in Myanmar but also to other similar countries to solve housing shortage problems and creating conditions of equity and affordability for low-income households. 


\section{References}

ADB. (2019) Financing affordable housing in Yangon. Manila: Asian Development Bank.

Carrasco, B. and Shan, S.A.M. (2018) 'How to address the lack of affordable housing in Asia', Asia Development Blog, February [online]. Available at: https://blogs.adb.org/print/blog/how-addresslack-affordable-housing-asia (Accessed: 2 February 2020)

Chen, J., Guo, F., and Zhu, A. (2011) 'The housing-led growth hypothesis revisited: Evidence from the Chinese provincial panel data', Urba Stud, 48(10), pp. 2049-2067.

Chen, Y.L. (2011) 'New prospects for social rental housing in Taiwan: The role of housing affordability crises and the housing movement', International Journal of Housing Policy, 11(3), pp. 305-318.

Chiu, R.L.H. (2013) 'The transferability of public housing policy within Asia: reflections from the Hong Kong-Mainland China case study' in Chen, J. et al. (eds.) The future of public housing: Ongoing trends in the East and the West. Berlin: Springer, pp. 3-12.

Haque, M.S. (2004) 'Governance and bureaucracy in Singapore: Contemporary reforms and implications', Int. Political Sci. Rev., 25(2), pp. 227-240.

Heeckt, C. et al. (2017) Towards urban growth analytics for Yangon: A comparative information base for strategic spatial development. London: London School of Economics and Political Science.

JICA. (2013) Final report on data collection survey on housing sector in Thailand. Thailand: National Housing Authority.

Joo, T.T.K. and Wong, T.C. (2008) 'Public housing in Singapore: A sustainable housing form and development' in TC Wong, T.C., Yuen, B.K. and Goldblum, C. (eds.). Spatial planning for a sustainable Singapore. Berlin: Springer, pp. 135-150.

Kouri, M.K., Hofer, K., Sallam, N. and Amalysyah, A.B.A. (2020) Grounded learning: people-centred approaches to housing in Yangon and Yogyakarta. London: UCL.

Kraas, F., Gaese, H. and Kyi, M.M. (2006) Megacity Yangon: transformation process and modern development, second Germany-Myanmar workshop in Yangon/ Myanmar. 1st ed. Germany: LIT Verlag Munster.

Lall, R., Mitra, S. and Sakuma, S. (2018) Grounded development: reflections on community-based practices in Sri Lanka and Myanmar. London: UCL.

Laws and Regulations Database of The Republic of China. (2017) '住宅法' [online]. viewed Available at: https://law.moj.gov.tw/LawClass/LawAll.aspx?pcode=D0070195 (Accessed: 15 June 2021)

Leeruttanawisut, K. and Fukushima, S. (2017) 'An evaluation of the Baan Eua Arthon housing program in Thailand: risks of a populist housing policy', Urban and Regional Planning Review, 4, pp. 168-184.

Lum, S.K. (2002) 'Market fundamentals, public policy and private gain: House price dynamics in Singapore', J. Property Res., 19(2), pp. 121-143.

Ministry of Interior. (2019) '不動產資訊平' [online]. Accessed at: https://pip.moi.gov.tw/V3/B/SCRB0501.aspx?mode=6 (Accessed: 15 June 2021)

Ministry of Interior. (2020) '房價負擔能力指標統計' [online]. Accessed at: https://pip.moi.gov.tw/Upload/CustomFile/Doc/109Q4\%E8\%B2\%A0\%E6\%93\%94\%E8\%83\%BD\%E5 \%8A\%9B\%E7\%99\%BC\%E5\%B8\%83\%E5\%85\%A7\%E5\%AE\%B9(\%E5\%B9\%B3\%E5\%8F\%B0).pdf (Accessed: 15 June 2021) 
Ministry of Interior. (2021) '包租代管計畫' [online]. Accessed at: https://pip.moi.gov.tw/V3/B/SCRB0504.aspx (Accessed: 15 June 2021)

Naing, M. and Nitivattananon, V. (2020a) 'Comparison of issues and countermeasures among previous and current squatter formations in Yangon, Myanmar', Current Urban Studies, 8, pp. 396-416.

Naing, M. and Nitivattananon, V. (2020b) 'Analysis of the housing market with the roles of private housebuilders on the middle-income group segment in Yangon, Myanmar', Journal of Construction in Developing Countries, 25(1), pp. 83-108.

Naing, M. (2021) 'Influencing factors for the growth of informal rental housing in Yangon, Myanmar', Current Urban Studies, 9, pp. 40-65.

Nwal, S.S. and Panuwatwanich, K. (2018) 'Social housing in Myanmar: issues and way forward' in Proceedings of the 2018 Joint Asia-Pacific Network for Housing Research and Australian Housing Researchers Conference, pp. 251-263.

Phang, S.Y. (2018) 'Transferability of Singapore's housing policy innovations' in Policy innovations for affordable housing in Singapore: Palgrave advances in regional and urban economics. Switzerland: Springer International Publishing, pp. 187-201.

PwC. (2018) Doing business in Yangon 2018. Singapore: PricewaterhouseCooper.

RCIS. (2019) International models for delivery of affordable housing in Asia. London: Royal Institution of Chartered Surveyors.

Stepehns, M. (2010) 'Locating Chinese urban housing policy in an international context', Urban Study, 47(14), pp. 2965-2982.

Wei, Z., Chen, T., Chiu, R.L.H. and Chan, E.H.W. (2017) 'Policy transferability on public housing at the city level: Singapore to Guangzhou in China', Journal of Urban Planning and Development, 143(3). 